\title{
IDENTIFICATION AND GROWTH CHARACTERIZATION OF A NOVEL 2,4-D (DICHLOROPHENOXYACETIC ACID) DEGRADING BACTERIUM MARIBACTER SP AMSU ISOLATED FROM AQUACULTURE EFFLUENT
}

\author{
SANKARALINGAM, S. ${ }^{1}$ - NithYANAND, P. $^{2}$ - KARUTHAPANDIYAN, S.T. ${ }^{2}$ - PALAVESAM, A. ${ }^{1}$ - \\ RAMASUBBURAYAN, R. ${ }^{1}$ - IMMANUEL, G. ${ }^{1} *$ \\ ${ }^{1}$ Centre for Marine Science and Technology, M.S.University, \\ Rajakkamangalam- 629 502, Kanyakumari District, Tamilnadu, India \\ ${ }^{2}$ Department of Biotechnology, Alagappa University, \\ Karaikudi, Tamilnadu, India \\ *Corresponding author \\ e-mail:gimmas@gmail.com
}

(Received $1^{\text {st }}$ November 2009; accepted $29^{\text {th }}$ January 2013)

\begin{abstract}
A bacterial isolate Maribacter sp AMSU, capable to degrade the herbicide 2,4-D (dichlorophenoxyacetic acid) was isolated from aquaculture effluent by enrichment culture technique. This isolate exhibited substantial growth in mineral salt medium supplemented with 2,4-D as a sole source of carbon and energy. Based on the morphological, cultural and biochemical characteristics, the isolate was identified as Maribacter sp according to Bergy's manual. The isolated bacterial strain was further identified by sequence analysis of its $16 \mathrm{~S}$ rRNA gene. Growth curve experiment on 2,4-D degradation indicated that 50 to $200 \mathrm{mg} / 100 \mathrm{ml}$ stimulated the bacterial growth during 24 to $48 \mathrm{~h}$ of incubation. However the bacterial growth was sustained and a significant death was observed with culture media containing $800 \mathrm{mg} / 100 \mathrm{ml}$ 2,4-D and above. At regular time intervals the optical density was measured at $600 \mathrm{~nm}$. Growth of the isolate was determined by viable cell enumeration immediately after inoculation. The growth of Maribacter sp in medium containing $50 \mathrm{mg} / 100 \mathrm{ml}$ to $200 \mathrm{mg} / 100 \mathrm{ml} 2,4-\mathrm{D}$ was not varied much during 24 to $48 \mathrm{~h}$, and the total viable count of 121 and $144 \times 10^{-4} \mathrm{CFU}^{-1} \mathrm{ml}^{-1}$ were observed, respectively. Media optimization results indicated that lactose (carbon) and ammonium chloride (nitrogen) added medium at $\mathrm{pH} 7$ and $35^{\circ} \mathrm{C}$ found to be suitable for the better growth of Maribacter sp. But lead added medium inhibited the growth of Maribacter sp. Degradation of 2,4D in culture supernatant was determined by using HPLC and the result obtained was discussed.
\end{abstract}

Keywords:biodegradation, dichlorophenoxyacetic acid (2,4-D), pesticides, Maribacter sp.

\section{Introduction}

In India, alarming levels of pesticides have been reported in air, water, soil as well as in foods and biological materials (Viswanathan, 1985; Agarwal et al., 1986; Nawab et al., 2003). The most important pollutants among the toxicants in India are organo chlorine and organo phosphorus pesticides. The later type is tending to replace the previous type to its fast degradation in the environment (Jiries et al., 2002). One way to enhance the break down of these chemicals is bioaugmentation by inoculation of microorganisms that are known to readily metabolize these chemicals (Ramadan et al., 1990).

Metabolically versatile bacterial species namely Arthrobacter sp and Pseudomonas sp can degrade a wide range of compounds including aromatic compounds (Sanni and Ajesebuter, 2003; Igbinosa, 2007). A series of growth curve experiment was performed with specific doses of pesticides (Malathion, Methamidophos, Cartap and 
Cypermethrin) in order to determine the viable count of Pseudomonas sp and to verify whether they could utilize these compounds for their growth (Jilani and Altafkhan, 2004). As growth kinetic studies provide an evidence of mineralization potential of organisms, such studies were conducted by several researchers while performing pesticide degradation using isolated strains of microbes (Karpouzas et al., 2000). Previous reports revealed that the microbial degradation process detoxifies the pesticide contaminations and it can be effectively used to overcome the pollution problems (Bhadhade et al., 2002). Soil bacteria with the ability to degrade several pesticides have been isolated from soil showing enhanced biodegradation, which includes a metamitron degrading bacterium, Rhodococcus sp (Parekh et al., 1994); chlorpyrifos- degrading Flavobacterium sp (Mallick et al., 1999); atrazine degrading bacterium Pseudomonas sp (Ralebits et al., 2002) and an idopropane degrading bacterium Arthrobacter sp (Mercadier et al., 2002). 2,4-D is one of the most commonly used herbicides in agriculture and gardening and it exhibits serious ecological effects. Regardless, it has toxic effects on birds, beneficial insects, soil annelids, and non- target plants. It also showed negative impacts on aquatic life, especially algae, small invertebrates, amphibians and fishes, particularly in their juvenile stages (Cox, 1999). Ingestion of high doses of 2,4-D have shown acute toxicity in lower mammals and humans and most of the strains have been well characterized (Fulthorpe et al., 1996). The catabolic pathway of 2,4-D mineralization by Ralstonia eutropha Jmp134 was investigated by Leveau et al (1999), Don and Pemberton (1981) and more recent studies have also elucidated the kinetics of 2,4-D degradation. The kinetics of cell growth and biodegradation of 2,4-D of microorganisms growing on herbicide was also reported by Muller et al (2001) and Fuchslin (2003). However no studies have been carried out on screening the 2,4-D degrading bacteria from aquaculture effluent and hence the present work was undertaken.

\section{Materials and methods}

\section{Chemicals}

Commercial grade 2,4-D was purchased from Sigma- Aldrich co, Bangalore, India, with purity higher than $98 \%$ and used throughout the experiment, because it would closely represent the nature of the active compound.

\section{Isolation and maintenance of 2,4-D degrading bacterium}

The bacterial species used in this study was isolated from aquaculture effluent. The bacterial strain was initially screened by the enrichment technique (Igbinosa, 2007). The effluent sample was collected aseptically from the aquaculture farming area nearby Rajakkamangalam estuary, Kanyakumari District, Tamilnadu, India. Then it was transported to the laboratory immediately for further studies. The effluent sample was exposed to high $(1000 \mathrm{mg} / 100 \mathrm{ml})$ concentration of $2,4-\mathrm{D}$ and this particular concentration used to obtain only the organisms which were capable to withstand. Then the screened bacterial strain was picked up and streaked on nutrient agar plate and restreaked in nutrient agar slants for further studies. The isolated bacterial strain was further cultured in 50ml nutrient broth containing $0.2 \%$ 2,4-D and kept in an incubator shaker at $35^{\circ} \mathrm{C}$ for $24 \mathrm{~h}$. Subsequently $0.2 \mathrm{ml}$ of this culture was streaked on mineral salt agar (MSM) g/l of $\left((\mathrm{NH} 4)_{2} \mathrm{SO}_{4} 1.0 ; \mathrm{Na}_{2} \mathrm{HPO}_{4} 2.1 ; \mathrm{MgSO}_{4} 0.01 ; \mathrm{CaCl}_{2} 2 \mathrm{H}_{2} \mathrm{O}\right.$ 0.1; 
$\mathrm{FeSO}_{4} 7 \mathrm{H}_{2} \mathrm{O} 0.001 ; \mathrm{CuSO}_{4} 0.04$ and $\mathrm{NaMOO}_{4}$ 0.002) supplemented with $0.2 \%$ 2,4-D plates and incubated at $35^{\circ} \mathrm{C}$ for $24 \mathrm{~h}$. Individual colonies were sub cultured on nutrient agar plates containing $0.2 \%$ 2,4-D until the pure cultures were isolated (Jilani and Altafkhan, 2004). After incubation, the isolated colonies were identified following the methods described in Bergey's manual of Determinative Bacteriology (Altschul et al., 1997).

\section{Strain identification}

\section{Genomic DNA extraction}

The bacterial isolate was grown in $2 \mathrm{ml}$ Zobell Marine Broth (HiMedia cat \#) overnight at $27^{\circ} \mathrm{C}$. The culture was centrifuged at $7000 \mathrm{rpm}$ for $3 \mathrm{~min}$. The pellet was resuspended in $400 \mu \mathrm{l}$ of sucrose TE and lysozyme was added to this to a final concentration of $8 \mathrm{mg} / \mathrm{ml}$ and incubated for $1 \mathrm{~h}$ at $37^{\circ} \mathrm{C}$. To this tube, $100 \mu \mathrm{l}$ of $0.5 \mathrm{M}$ EDTA (pH 8.0), $60 \mu 1$ of $10 \%$ SDS and $3 \mu 1$ of proteinase $\mathrm{K}$ from $20 \mathrm{mg} / \mathrm{ml}$ were added and again incubated at $55^{\circ} \mathrm{C}$ overnight. The supernatant was extracted twice with phenol: chloroform (1:1) and once with chloroform: isoamylalcohol (24:1) and ethanol was precipitated. Finally the DNA pellet was resuspended in sterile distilled water.

\section{Amplification of $16 \mathrm{~S}$ rDNA gene}

Bacterial 16S rDNA was amplified from the extracted genomic DNA using the following universal eubacterial 16SrDNA primers: forward primer 5' AGAGTTTGATCCTGGCTCAG $3^{\prime}$ and reverse primer 5' ACGGCTACCT TGTTACGACTT 3'. Polymerase chain reaction was performed in a $50 \mu 1$ reaction mixture containing $2 \mu \mathrm{l}(10 \mathrm{ng})$ of DNA as the template, each primer at a concentration of $0.5 \mu \mathrm{M}, 1.5 \mathrm{mM} \mathrm{MgCl}_{2}$, and each deoxynucleoside triphosphate at a concentration of $50 \mu \mathrm{M}$, as well as $1 \mathrm{U}$ of $\mathrm{Taq}$ polymerase and buffer as recommended by the manufacturer (MBI Fermentas). After the initial denaturation for $3 \mathrm{~min}$ at $95^{\circ} \mathrm{C}$, there were 40 cycles consisting of denaturation at $95{ }^{\circ} \mathrm{C}$ for $1 \mathrm{~min}$, annealing at $55^{\circ} \mathrm{C}$ for 1 min, and extension at $72{ }^{\circ} \mathrm{C}$ for $2 \mathrm{~min}$ and then a final extension step consisting of $5 \mathrm{~min}$ at $72{ }^{\circ} \mathrm{C}$; Mastercycler Personal (eppendorf, Germany) was used. The amplification of $16 \mathrm{~S}$ rDNA was confirmed by running the amplification product in $1 \%$ agarose gel in $1 \mathrm{X}$ TAE.

\section{Cloning and sequencing of $16 \mathrm{~S}$ rDNA gene}

The amplified product (1,500-bp) was purified using GFX TM PCR DNA and Gel Band Purification Kit (Amersham Biosciences) according to manufacturer's instruction. The 16S rDNA amplicon was cloned in pTZ57R/T vector according to the manufacturer's instruction (InsT/Aclone ${ }^{\mathrm{TM}}$ PCR Product Cloning Kit \#K1214, MBI Fermentas). Full length sequencing of the rDNA gene (about $1500 \mathrm{bp}$ ) for the isolated bacteria was carried out in Macrogen (Seoul, Korea).

\section{Nucleotide sequence analysis}

The full-length sequences obtained were matched with previously published sequences available in NCBI using BLAST (Altschul et al., 1997). Multiple sequence analysis was carried out using CLUSTALX (Thompson et al., 1997) and further NJ plot (Perrière and Gouy, 1996) and PhyloDRAW were employed for constructing 
phylogenetic tree. To validate the reproducibility of the branching pattern, a bootstrap analysis was also performed.

\section{Growth kinetics of 2,4-D degrading bacterium}

The tolerance of bacterium was studied by the method of Gupta et al (1994). The mineral salt medium was used to investigate the degradation potential of isolated bacterial strain of Maribacter sp. One loopful of isolated bacterial strain was inoculated into freshly prepared nutrient broth containing $0.2 \% 2,4-\mathrm{D}$ as the sole source of carbon. For the determination of growth kinetics, aliquots $(2.5 \mathrm{ml})$ of $24 \mathrm{~h}$ culture inoculated into eight flasks containing $100 \mathrm{ml}$ mineral salt medium supplemented with 2,4-D. The concentrations tested were $50,100,150,200,400,600,800$, and $1000 \mathrm{mg} / 100 \mathrm{ml}$. The culture was incubated in shaker at $35^{\circ} \mathrm{C}$ for $24 \mathrm{~h}$. Turbidity was used as an index of biodegradation potential. Three replicates were maintained for each concentration of 2,4-D through out the experimental studies. The lowest concentration of 2,4-D which inhibited the growth of the organism was considered as MIC. At regular time intervals the optical density was measured at 600nm (Mussarat et al., 2000). The growth curve was obtained by plotting the optical density as a function of time.

\section{Enumeration of viable cell count}

The viable cell colonies were counted by the method described by Collins and Lyne (1985). The isolated bacterial culture was enumerated with and without addition of 0.2 $\%$ 2,4-D. Aliquots of $1 \mathrm{ml}$ of $24 \mathrm{~h}$ culture was inoculated into $50 \mathrm{ml}$ mineral salt medium (Broth) containing different concentrations of 2,4-D and growth was tested. Then $1 \mathrm{ml}$ of the bacterial sample from each concentration was drawn at regular intervals and serial dilutions were performed using $9 \mathrm{ml}$ of sterile blank. Appropriate dilutions of bacterial sample were plated in triplicate nutrient agar plates and were incubated at $35^{\circ} \mathrm{C}$ for $24 \mathrm{~h}$. After inoculation, growth of the isolated bacterial strain was studied with the help of microscope by viable cell enumeration.

\section{Optimization of media components for the growth of Maribacter sp}

\section{Effect of different carbon sources}

The effect of carbon sources on growth of Maribacter sp was individually determined by using different carbon sources such as glucose, sucrose, fructose, lactose and maltose supplemented in the basal medium at $0.5 \%$ concentration each (Kotresha and Vidyasagar, 2008). Here $0.1 \%$ culture broth was inoculated in to the culture media supplied with $0.2 \%$ 2,4-D and growth was measured at every $6 \mathrm{~h}$ interval.

\section{Effect of different nitrogen sources}

The effect of nitrogen source on growth of Maribacter sp was individually determined by using various nitrogen sources such as ammonium chloride, yeast extract, peptone, sodium nitrate and potassium nitrate supplemented in the basal medium at a concentration of $0.5 \%$ each (Kotresha and Vidyasagar, 2008). The culture medium was supplied with $0.2 \% 2,4-\mathrm{D}$, inoculated with $0.1 \%$ culture broth and the growth was measured at every $6 \mathrm{~h}$ interval. 


\section{Effect of different $\mathrm{pH}$}

The effect of optimum $\mathrm{pH}$ on degradation of 2,4-D by the experimental microorganism was determined by culturing the bacterium in $0.2 \% 2,4-\mathrm{D}$ supplemented medium with different $\mathrm{pH}(5,6,7,8$ and 9) and the growth was measured at every $6 \mathrm{~h}$ interval.

\section{Effect of different temperature}

The effect of temperature on degradation of 2,4-D was studied by altering the incubation temperature of the culture medium for the growth of Maribacter sp. In this experiment $0.1 \%$ culture broth was inoculated in different temperature $(20,30,35,40$, and $50{ }^{\circ} \mathrm{C}$ ) range and growth was measured at every $6 \mathrm{~h}$ interval (Margesin and Schinner, 1997).

\section{Effect of different heavy metals}

The effect of heavy metals on degradation of 2,4-D was determined by using various types of metals namely lead, zinc, copper, cadmium, ferrous iron, mercury and nickel (Kotresha and Vidyasagar, 2008). For the determination of degradation, aliquets $(2.5 \mathrm{ml})$ of $24 \mathrm{~h}$ culture was inoculated into $100 \mathrm{ml}$ mineral salt medium supplemented with $0.2 \%$ 2,4-D and $0.1 \%$ individual heavy metals. After $24 \mathrm{~h}$ of incubation, the degradation was studied by Turbidometric method (O.D).

\section{HPLC analyses}

Degradation of 2,4-D in culture supernatant was also determined by using HPLC (model No SPD70 AVP, SHIMADZU). For this $100 \mathrm{ml}$ of supernatant was taken from growing bacterial cultures and transferred in to $1.5 \mathrm{ml}$ micro centrifuge tubes. These were then centrifuged at $15,000 \mathrm{rpm}$ for 10 mins and the supernatant was collected, pooled and stored at frozen condition for HPLC studies. After incubation, samples were warmed at $35^{\circ} \mathrm{C}$ for 5 to $10 \mathrm{~min}$. and $70 \mu \mathrm{l}$ was transferred in to a $1.8 \mathrm{ml}$ amber auto sampler vial containing $730 \mu \mathrm{l}$ HPLC grade $\mathrm{H}_{2} \mathrm{O}$ and $50 \mathrm{mg}$ dissolved in $200 \mathrm{ml}$ acetonitrile: $80 \% \mathrm{H}_{2} \mathrm{O}$. Samples were eluted at a flow rate of $1.0 \mathrm{ml} / \mathrm{min}$ with $0.025 \%$ $\mathrm{H}_{3} \mathrm{PO} 4$ - acetonitrile gradient. Absorbance of eluted compounds was monitored at 210 $\mathrm{nm}$. Sample retention time was compared to known prepared standard and analyzed using identical protocols.

\section{Results and discussion}

\section{Isolation and identification of 2,4-D degrading bacteria}

A bacterium was isolated from the aquaculture effluent sample that was able to withstand high concentration of 2,4-D $(1000 \mathrm{mg} / 100 / \mathrm{ml})$. On the basis of morphological, cultural and biochemical characteristics of the isolated bacteria was identified as Maribacter sp (Table 1). 
Table 1. Morphological, cultural and biochemical tests for identification of the strain

\begin{tabular}{|c|c|}
\hline Tests & Strain Maribacter sp AMSU \\
\hline \multicolumn{2}{|c|}{ Morphological tests } \\
\hline Colony morphology & \\
\hline Configuration & Circular \\
\hline Margin & Entire \\
\hline Elevation & Convex \\
\hline Surface & Smooth and shiny \\
\hline Pigment & - \\
\hline Opacity & Opaque \\
\hline Gram's reaction & Negative \\
\hline Cell shape & Rods \\
\hline Size $(\mu \mathrm{m})$ & Length: $1-2 \mu$, Width: $\sim 1 \mu$ \\
\hline Arrangement & Singles \\
\hline Spores(s) & - \\
\hline Position & - \\
\hline Shape & - \\
\hline Sporangia & - \\
\hline Motility & + \\
\hline \multirow{2}{*}{\multicolumn{2}{|c|}{$\begin{array}{c}\text { Physiological tests } \\
\text { Growth at temperatures }\end{array}$}} \\
\hline & \\
\hline $4^{\circ} \mathrm{C}$ & - \\
\hline $15^{\circ} \mathrm{C}$ & $\mathrm{W}$ \\
\hline $20^{\circ} \mathrm{C}$ & + \\
\hline $25^{\circ} \mathrm{C}$ & + \\
\hline $30^{\circ} \mathrm{C}$ & + \\
\hline $37^{\circ} \mathrm{C}$ & + \\
\hline $42^{\circ} \mathrm{C}$ & + \\
\hline $52^{\circ} \mathrm{C}$ & - \\
\hline \multicolumn{2}{|l|}{ Growth at pH } \\
\hline $\mathrm{pH} 4.0$ & + \\
\hline pH 5.0 & + \\
\hline pH 6.0 & + \\
\hline $\mathrm{pH} 7.0$ & + \\
\hline $\mathrm{pH} 8.0$ & + \\
\hline $\mathrm{pH} 9.0$ & + \\
\hline \multicolumn{2}{|l|}{ Growth at $\mathrm{NaCl}(\%)$} \\
\hline 2.0 & + \\
\hline 5.0 & + \\
\hline 7.0 & - \\
\hline 10.0 & - \\
\hline Growth under anaerobic conditions & + \\
\hline Biochemical tests & Strain Maribacter sp AMSU \\
\hline Growth in MacConkey agar & + \\
\hline Indole test & - \\
\hline Methyl red test & - \\
\hline Voges Prauskauer & - \\
\hline Citrate utilization & + \\
\hline $\mathrm{H}_{2} \mathrm{~S}$ Production & - \\
\hline Gas from glucose & + \\
\hline Acid from glucose & + \\
\hline Acid from lactose & + \\
\hline Casein hydrolysis & - \\
\hline Esculin hydrolysis & - \\
\hline Gelatin hydrolysis & - \\
\hline Starch hydrolysis & - \\
\hline
\end{tabular}


Table 1. cont.

\begin{tabular}{c|c} 
Tests & Strain Maribacter sp AMSU \\
\hline Urea hydrolysis & Morphological tests \\
Nitrate reduction & + \\
Catalase test & + \\
Oxidase test & - \\
Lysine decarboxylase & - \\
Arginine dihydrolase & $\mathrm{W}$ \\
Ornithine decarboxylase & + \\
Tween 80 hydrolysis & - \\
Tween 40 hydrolysis & - \\
Phosphatase test & - \\
Lecithinase & - \\
ONPG test & - \\
DNase & - \\
Tyrosine & - \\
Hippurate & - \\
\hline
\end{tabular}

The isolated bacterial strain was described as Gram mucoid rods. It is a sugar fermenting bacterium and a non-acid gas producer. The results on phylogenetic studies revealed that the 16S rDNA of the strain Maribacter sp AMSU had 93\% similarity with the nearest match in the Genbank (accession number - EU624432) (Fig.1. Phylogenetic tree). This result is identical with the earlier report of Mussarat et al (Mussarat et al., 2000), Who reported that two Pseudomonas sp isolated from agricultural soil contaminated with 2,4-D, capable of utilizing 2,4-D as a source of carbon.

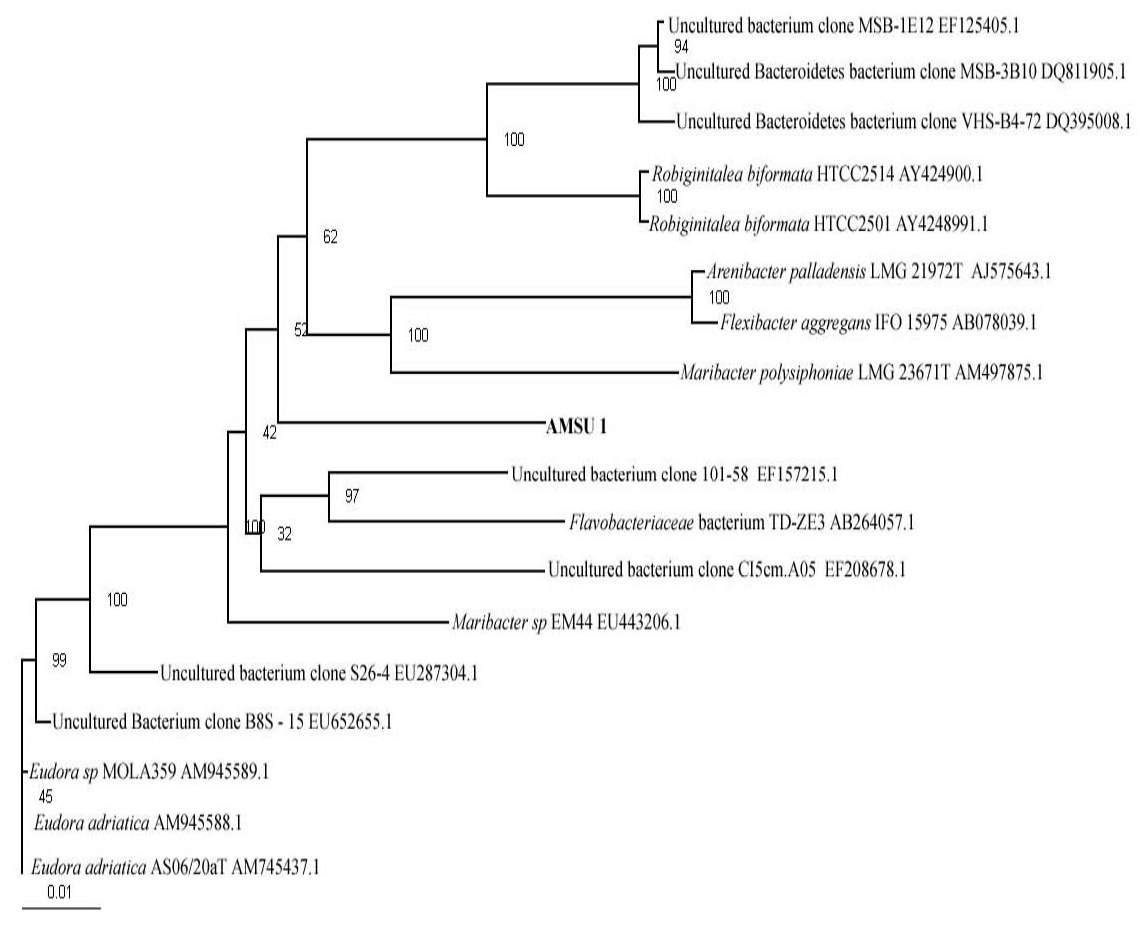

Figure 1. Phylogentic relationship of Maribacter sp AMSU with closelyrelated bacterial genera 


\section{Mineralization of 2,4-D}

HPLC (Fig. $2 \& 3$ ) analyses indicated that, 2,4-D was detected in medium containing $0.2 \% 2,4-\mathrm{D}$. The present result inferred that the retention time of the control medium recorded was 3.479 ( $\mathrm{min}$ ). Whereas the medium inoculated with bacterial strain supplemented with nutritional sources and 2,4 - D inferred almost same level of retention time with two peaks of 2.400 and 3.670 (min).

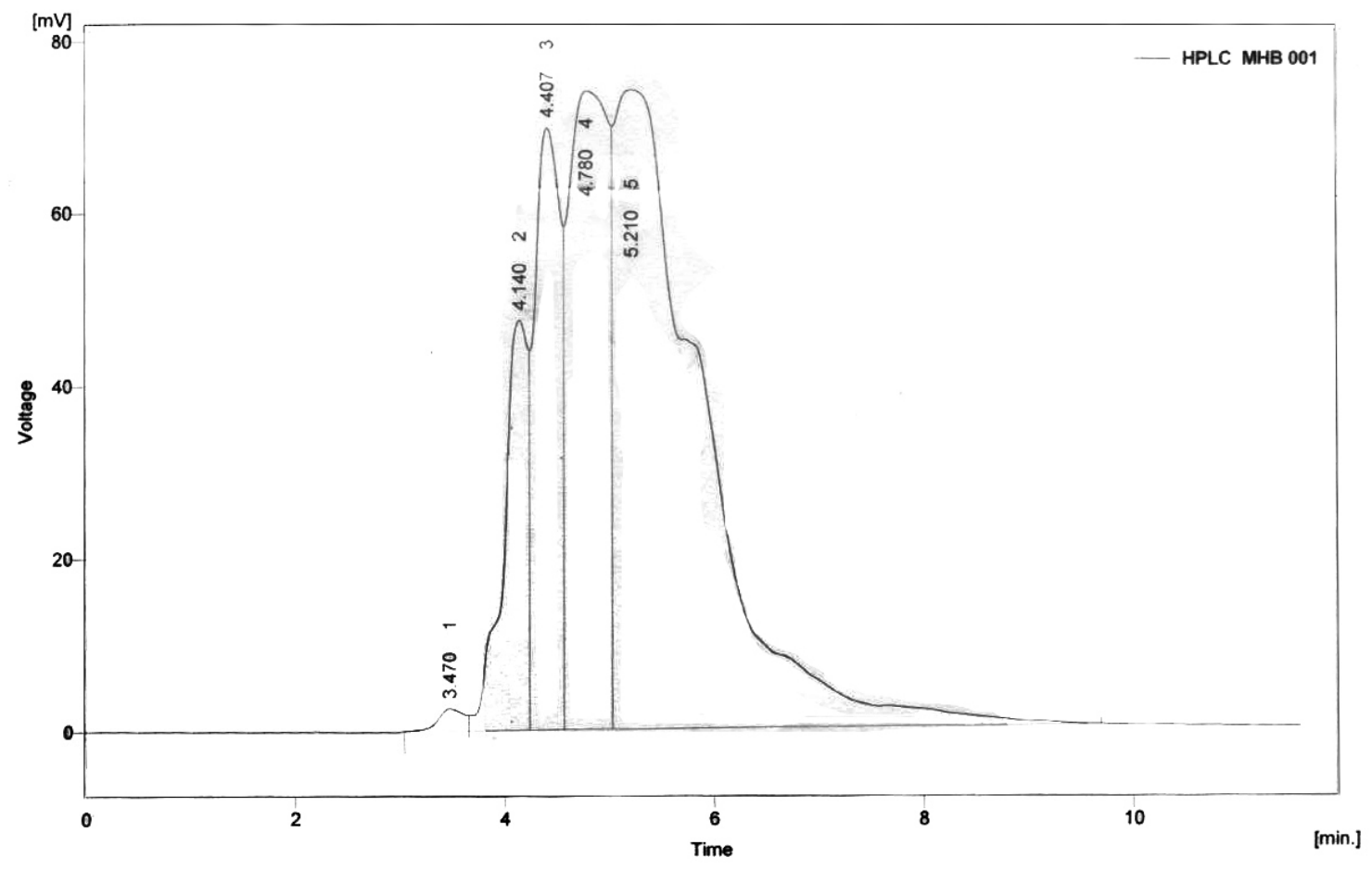

Result Table (Uncal - HPCL MHB 001)

\begin{tabular}{c|c|c|c|c|c|c}
\hline & $\begin{array}{c}\text { Reten. Time } \\
(\mathbf{m i n})\end{array}$ & Area [mV.s] & Height [mV] & Area [\%] & Height [\%] & WO5 (min) \\
\hline 1 & 3.470 & 43.039 & 2.498 & 0.5 & 0.9 & 0.30 \\
2 & 4.140 & 763.023 & 47.363 & 9.2 & 17.7 & 0.23 \\
3 & 4.407 & 1203.213 & 69.638 & 14.5 & 26.0 & 0.33 \\
4 & 4.780 & 1933.568 & 73.922 & 23.3 & 27.6 & 0.46 \\
5 & 5.210 & 4354.028 & 73.994 & 52.5 & 27.7 & 0.92 \\
& Total & 8296.871 & 267.415 & 100.0 & 100.0 & \\
\hline
\end{tabular}

Figure 2. HPLC profile of 2, 4-D supplied medium (control)

Here the results imply that 2,4-D was converted into Dichloro phenol and acetic acid. This pesent results was supported by the earlier studies of Christian et al (1999), who have reported that areobicd drgardation of mecoprop and dichloroprop were detected by using HPLC. Under anaerobic conditions, the concentrations of 2,4-D decreased exponentially and 2,4-D was the main metabolite of anaerobic degradation, only traces of 4-chlorophenol detected in the media. Rice et al (2005) also reported that 2,4,5-T and 2,4-D contaminated soil samples were analysed in HPLC. They observed that 2,4-D and $2,4,5-\mathrm{T}$ were observed in $73.8 \mathrm{mg} / \mathrm{Kg}$ and $23.4 \mathrm{mg} / \mathrm{Kg}$, respectively. During the process of degradation, the bacteria was greatly stressed and as a result, the growth was delayed in the medium supplemented with high concentration of 2, 4-D. Growth curve 
experiment with different concentrations of 2,4-D indicated that the concentration of 50 $\mathrm{mg}$ to $200 \mathrm{mg} / 100 \mathrm{ml}$ provoked an increase in bacterial growth during 24 to $48 \mathrm{~h}$ of incubation, whereas in medium added with $800 \mathrm{mg} / 100 \mathrm{ml}$, the growth was sustained. But in medium supplemented with $1000 \mathrm{mg} / 100 \mathrm{ml} 2,4-\mathrm{D}$, the growth of the organism was arrested and significant death was observed (Fig. 4). Further the results indicated that in $200 \mathrm{mg} / 100 \mathrm{ml} 2,4-\mathrm{D}$, the growth of Maribacter sp was not affected much and it was compared with control experiment.

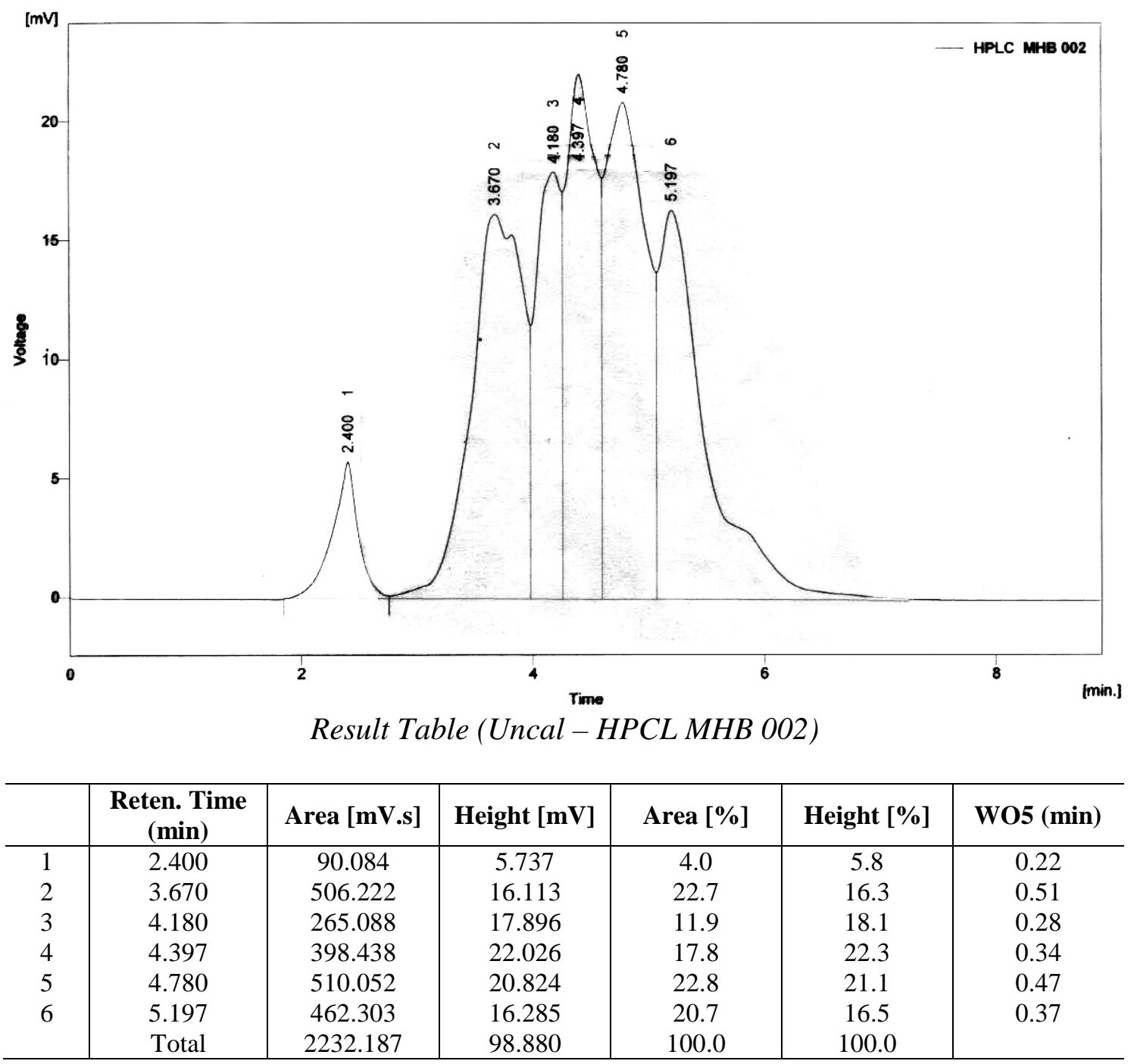

Figure 3. HPLC profile of 2, 4-D supplied medium inoculated with Maribacter spAMSU

The maximum growth was observed in $200 \mathrm{mg} / 100 \mathrm{ml} 2,4-\mathrm{D}$ added medium against the minimum growth in $1000 \mathrm{mg} / \mathrm{ml}$. These results indicated that high concentrations of 2,4-D become toxic to the organism and therefore this isolate was unable to utilize 2,4$\mathrm{D}$ at this concentration. Further 2,4-D at $50 \mathrm{mg}$ to $200 \mathrm{mg} / 100 \mathrm{ml}$ did not show any toxic effect to the Maribacter sp when compared to those organisms grown in 400mg to $1000 \mathrm{mg} / 100 \mathrm{ml}$. This result is identical with earlier report of Jilani \& Altafkhan (2004), who reported that the growth curve experiment with different concentrations (60 to $80 \mathrm{mg} / 100$ ) of cartap pesticides provoked a bacterial growth. Mussarat et al. (2000) have 
also reported that two Pseudomonas sp isolated from agricultural soil contaminated with 2,4-D capable of utilizing 2,4-D as a source of carbon. Most of the strain can able to grow well in simple minimal media with a single organic compound as carbon and energy source (Palleroni, 1986).

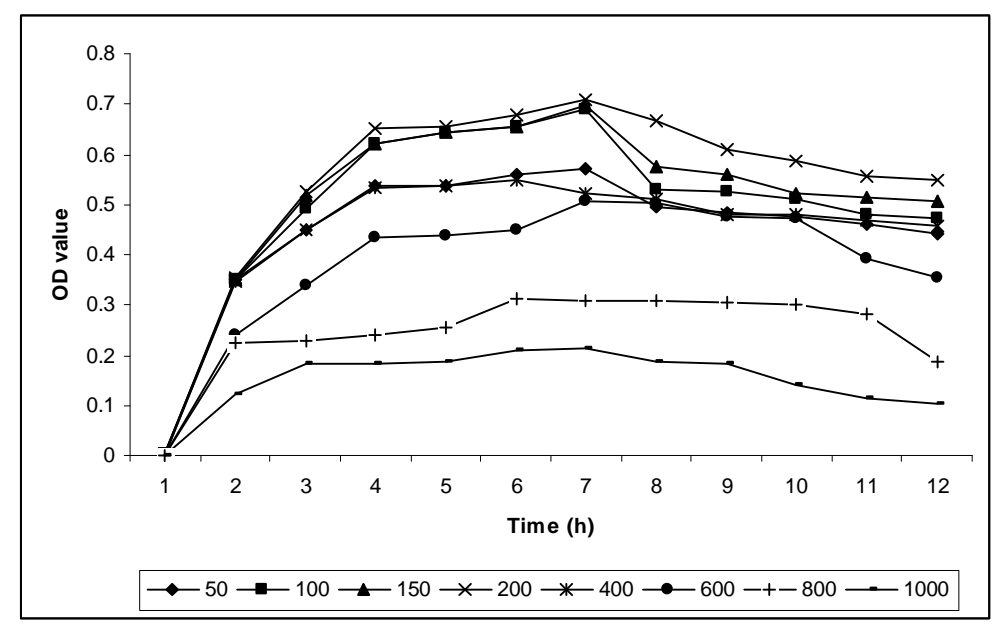

Figure 4. Effect of different concentration of 2,4-D on growth of Maribacter sp AMSU

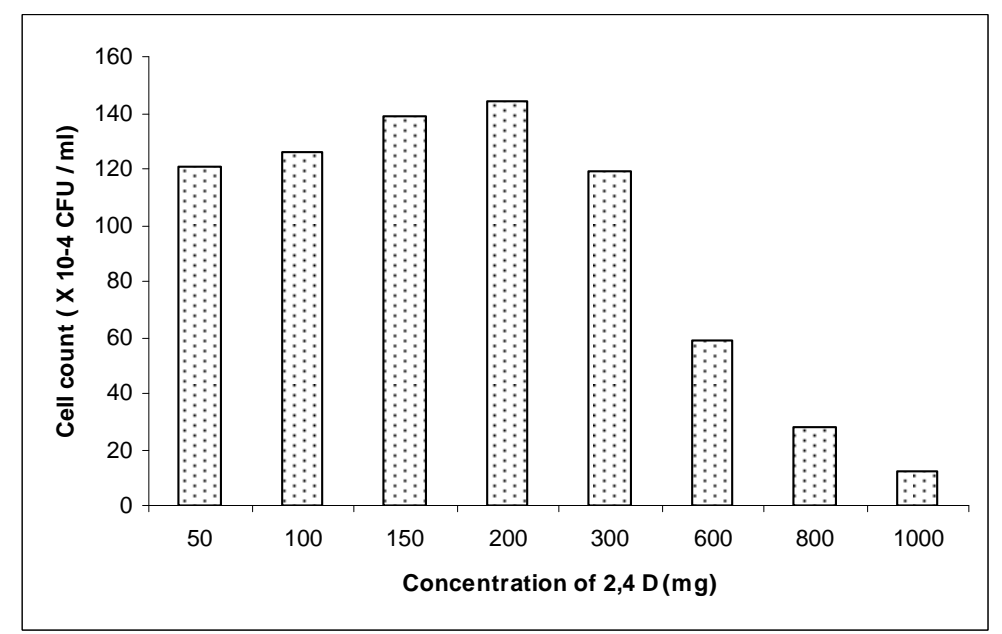

Figure 5. Enumeration of viable cell count of Maribacter spAMSU cultured in different concentrations of 2,4-D

\section{Enumeration of viable cell count}

The growth of Maribacter sp was not varied much in medium containing $50 \mathrm{mg} / 100 \mathrm{ml}$ to $200 \mathrm{mg} / 100 \mathrm{ml} 2,4-\mathrm{D}$, where the total viable count observed was between 121 and $144 \times 10^{-4} \mathrm{CFU} \cdot \mathrm{ml}^{-1}$. The results indicated that 2, 4-D concentrations in the range of $50 \mathrm{mg}$ to $200 \mathrm{mg} / 100 \mathrm{ml}$ did not affect the growth of the isolated bacterium. However, marked reduction in bacterial count at $24 \mathrm{~h}$ was recorded in the medium containing $1000 \mathrm{mg} / 100 \mathrm{ml} \mathrm{2,4-D.} \mathrm{These} \mathrm{results} \mathrm{indicated} \mathrm{that} \mathrm{high} \mathrm{concentration} \mathrm{of}$ 2,4-D inhibited the bacterial growth. During the process of degradation, it was observed 
that in the presence of high concentration of 2,4-D, the bacteria was stressed much and in consequence the growth was reduced (Fig. 5). Another believable explanation is that microorganism may need an accumulation period to induce the necessary dagradative enzymes to degrade the organic compound and the prolonged log phase observed high concentration of 2,4-D (Mussarat et al., 2000).

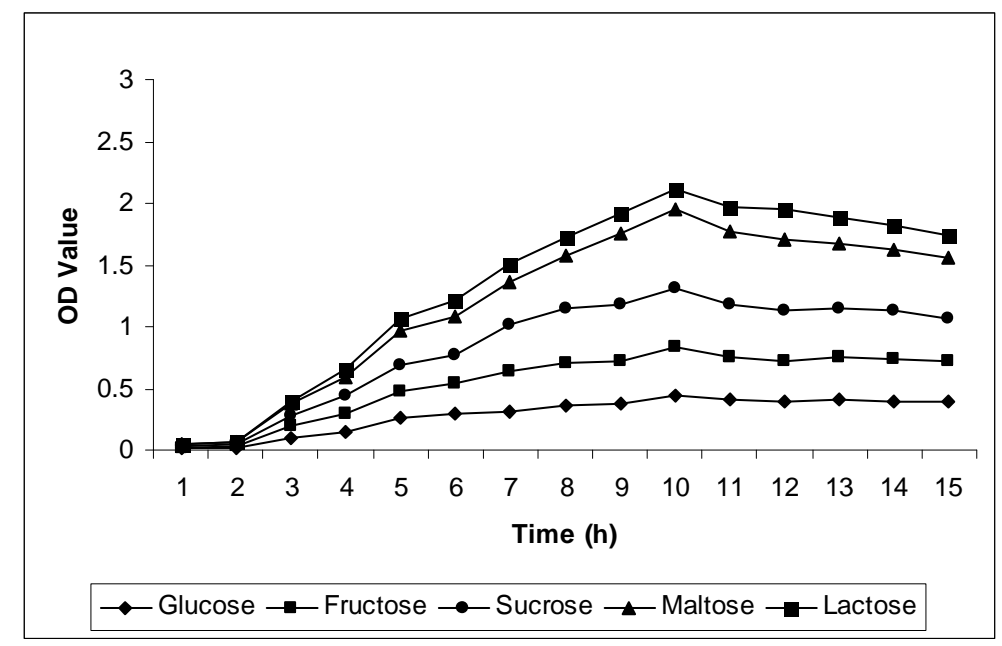

Figure 6. Effect of different carbon sources on growth of Maribacer sp AMSU

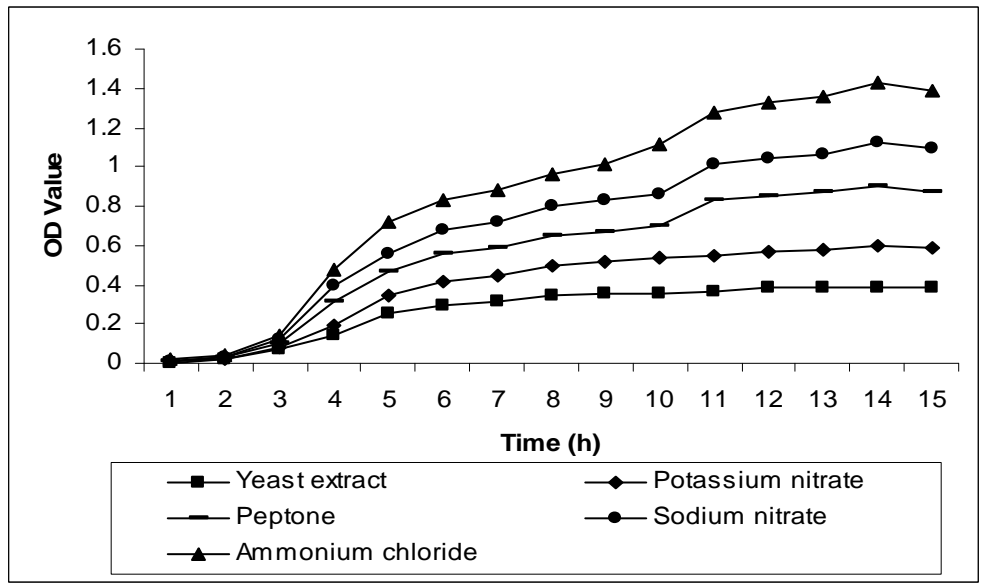

Figure 7. Effect of different nitrogen sources on growth of Maribacter sp AMSU

\section{Media optimization}

Experimentation on the carbon sources on growth of Maribacter sp AMSU indicated that, the growth was maximum in medium supplemented with lactose (Fig. 6). María Celina and Marisa Anahí (2005) have reported that the phenotypic diversity of rhizobia belonging to the main genera of rhizobial bacterial strains that colonize the same soil, by assessing the growth different bacterial strains in the presence of herbicides and the ability of these strains to utilize different energy and carbon sources. Likewise among the nitrogen sources tested, the growth of Maribacter sp AMSU was high in medium supplemented with Ammonium chloride (Fig. 7). This report is harmonizing with the 
earlier report on Kale et al (2005), who observed that the degradation and growth rate of A. chroococcum was not affected at $0.5-5 \mathrm{ppm}$ carbofuran in nitrogen supplemented medium. Rice et al (2005) have reported that Burholderia sp JR7 B2 and Burholderia sp JR7 B3 were able to mineralize 2,4,5-T in the presence of $0.01 \%$ yeast extract.

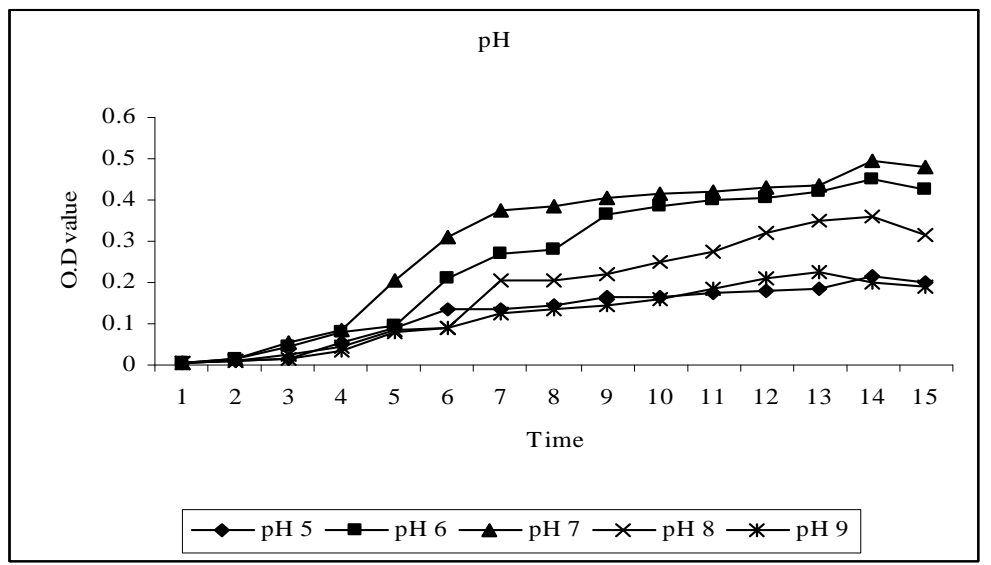

Figure 8. Effect of different $p H$ on growth of Maribacter sp AMSU

In the present study, among the media tested with $\mathrm{pH} 5$ to 9 , the growth of Maribacter sp AMSU was maximum at pH 7 (Fig. 8) and it was found to be optimum for enhancing the 2,4-D degradation. This report is idencal with the earlier report of Mussarat et al (2000). They reported that the optimum growth in mineral medium at $\mathrm{pH}$ 7 clearly indicated their capability to utilize 2,4-D as source of carbon and energy. Among the temperature $\left(20\right.$ to $\left.50{ }^{\circ} \mathrm{C}\right)$ tested, Maribacter sp attained maximum growth at $35{ }^{\circ} \mathrm{C}$ and the minimum growth was registered at $50{ }^{\circ} \mathrm{C}$ (Fig. 9). This result was identical with the earlier report of Cookson (1995), he reported that the microorganisms found effective in bioremediation have been shown to perform well in the temperature range of 10 to $40^{\circ} \mathrm{C}$.

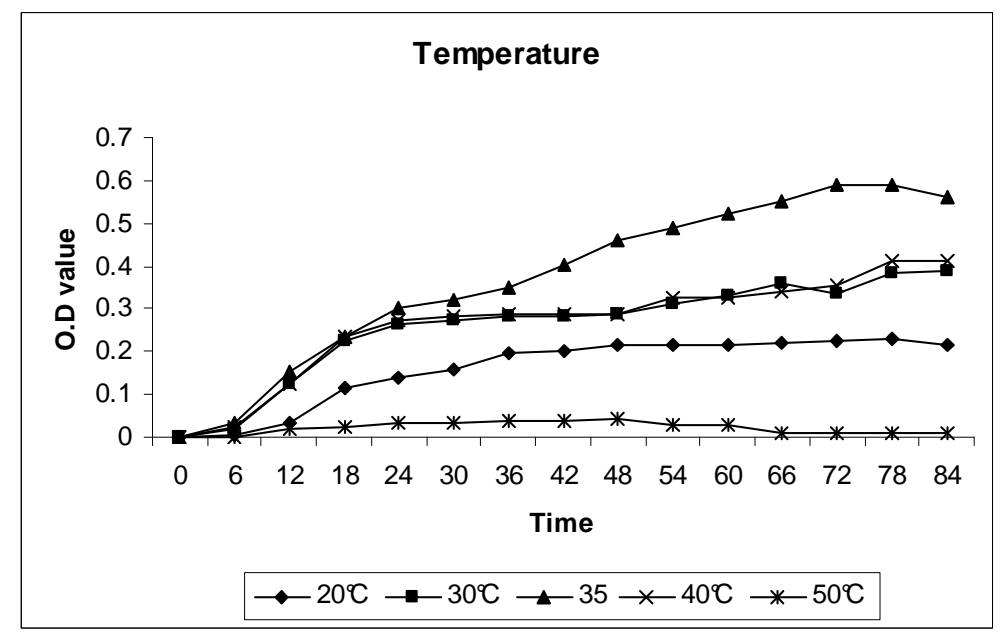

Figure 9. Effect of different temperature on growth of Maribacter sp AMSU 
The effect of heavy metals revealed that lead has inhibited the growth of Maribacter sp more effectively when compared with the other tested heavy metals (Fig. 10). Roane et al. (2001) reported that cadmium added at a level of $60 \mathrm{mg} / 1$ was found to inhibit the biodegradation of 2,4-D in soil system inoculated with the 2,4-D degrader Alcaligens eutrophus. The impact of copper toxicity on biodegradation of biodegradable polymer and Polyhydroxybutyrate (PHB), have been investigated by Birch and Brandl (1996). The authers found that $8-15 \mathrm{mg} / \mathrm{l}$ were required to inhibit PHB degradatioin. BenkaCoker and Ekundayo (1998) investigated the impact of lead, copper and mangenase on crude oil biodegrdation by a Micrococcus sp and Pseudomonas sp. This biodegradation was reduced by zinc at low concentration of $0.43 \mathrm{~g} / 1$ and least by manganese at $28.2 \mathrm{mg} / \mathrm{l}$. Kuo and Genthener (1996) investigated that the addition of low levels of metals $(0.1-2.0 \mathrm{mg} / \mathrm{l})$ prolonged the acclimitation period and decreased dechlorination and biodegradation process. From these findings it is evident that Maribacter sp AMSU could be a better bacterium for the biodegradation of agricultural effluent contaminated with 2,4-D pesticides.

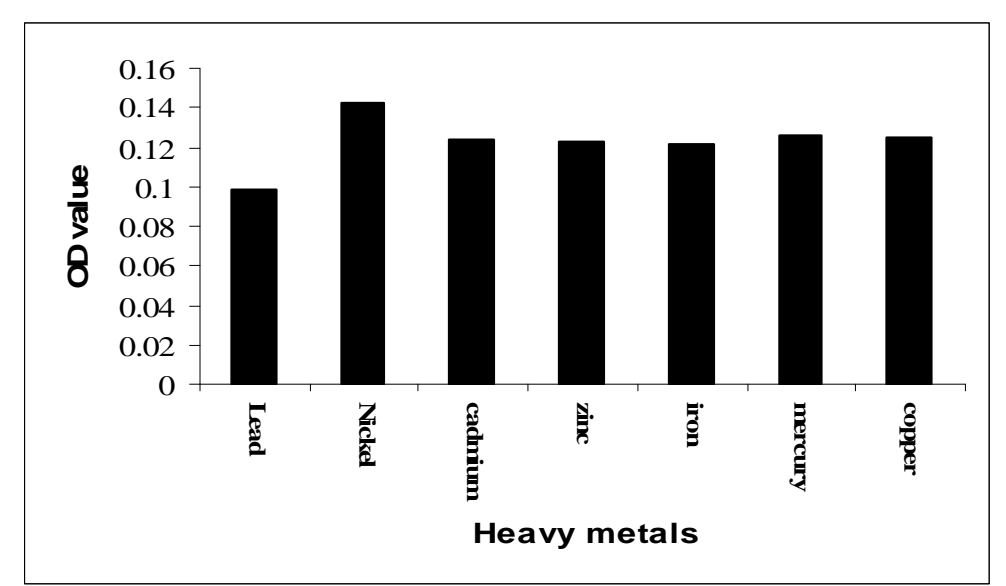

Figure 10. Effect of different heavy metals on degradation of 2,4-D by Maribacter sp AMSU

\section{Conclusions}

The bioaugmentation of polluted soil has already been studied by many authors . But, in many cases the introduced bacteria fail to degrade the pollutants due to their poor survival or low activity. The present study is the unique report on the isolation of 2,4-D bacteria from aquaculture effluent. The isolated bacterium appears to be a novel and it shares just $93 \%$ similarity with the closest match in Genbank. The isolated bacterium showed substantial growth in mineral media containing 2,4-D as a sole source of carbon and energy. During the process of degradation, the growth of the becterium was high in medium containing $200 \mathrm{mg} / 100 \mathrm{ml} 2,4-\mathrm{D}$. While the medium containing $1000 \mathrm{mg} / 100 \mathrm{ml}$ the bacterium was greatly streased. Growth of the isolate was determined by viable cell enumeration immediately after inoculation. The rate of degradation of 2,4-D in culture supernatants was studied by using HPLC. Media optimization results indicated that lactose (carbon) and ammonium chloride (nitrogen) added medium at $\mathrm{pH} 7.0$ and at $35^{\circ} \mathrm{C}$ temperature found to be suitable for the better growth of Maribacter sp. But lead added medium inhibited the growth of Maribacter $\mathrm{sp}$. 


\section{REFERENCES}

[1] Agarwal, H.C., Mittal, P.K., Menon. K.B., Pillai, M.K.K. (1986): DDT residues in the river Jammu in Delhi, India. - Water, Air, Soil Poll. 28: 89-104.

[2] Altschul, S.F., Madden, T., Schaffer, A.A., Zhang, J., Anang, Z., Miller, W., Lipman, D.J. (1997): Gapped BLAST and PSI-BLST: a new generation of protein database search programs. - Nucleic Acid Res. 25: 3389-3402.

[3] Benka-Coker, M.D., Ekundayo, J.A. (1998): Effects of heavy metals on growth of species of Micrococcus and Pseudamonas in a crude oil/mineral salts medium. - Biores. Technol. 66: 241-245.

[4] Bhadhade, B.J., Sarnaik Kanekar, S.S. (2002): Bioremediation of an industrial effluent containing monocrotophos. - Curr. Microbiol. 45(5): 346-349.

[5] Birch, L., Brandl, H. (1996): A rapid method for determination of metal toxicity to the biodegradation of water insoluble polymers. - Fresen J. Anals Chem. 354: 760 -762.

[6] Christian, Z., Christof, B., Thomas, F., Marc, J.F.S., Werner, A., Markus, D.M., Hans, P.E.K. (1999): Fate of herbicides mecoprop, dichloroprop and 2,4-D in aerobic and anaerboic sewage sludge as determined by laboratory batchsyudies and enantiomerspecific analysis. - Biodegrdation 10: 271-278.

[7] Collins, C.H., Lyne, P.M. (1985): Microbiological methods. $-5^{\text {th }}$ Edn., Butterworth and Co (Publishers) Ltd.

[8] Cookson, J.T. (1995): Bioremediation engineering: design and application. - New York, USA: McGraw-Hill Publising Co., 554 pp.

[9] Cox, C. (1999): 2,4-D: ecological effects. Herbicides fact shet. - J. Pest. Reform. 19(3): 14-9.

[10] Don, R.H., Pemberton, J.M. (1981): Properties of six pesticides degradation plasmids isolated from Alcaligens paradoxus and Alcaligenes eutrophs. - J. Bacteriol.. 145: 681686.

[11] Fuchslin, H.P., Riiegg, I., Van der Meer, J.R., Egli, T. (2003): Effect of integrations of a GFP reporter gene on fitness of Rlastonia eutropha during growth with 2,4Dicholorophenooxyacetate. - Environ. Microbiol. 5(10): 878-87.

[12] Fulthorpe, R.R., Rhodes, A.N., Tiedje, J.M. (1996): Pristine soils mineralize 3cholorobencoate and 2,4-Dicholorophenoxyacetic acid via different microbial population. - Appl. Enviorn. Microbiol. 62: 1159-1166.

[13] Gupta, N., Gaholt, R., Lakshiminarayana, N., Narula, K. (1994): Pesticide resistance among Azatobacter chrocoocum soil isolates and mutants. - Microbiol Res. 149: 391393.

[14] Holt, J.G., Noel, R.K., Sneath, P.H.A., Stanley, J.T., Williams, T. (1994): Bergey's manual of Determinative Bacteriology. - Vol:1-4, Williams \& Wilkins Co., Baltimore, $787 \mathrm{p}$.

[15] Igbinosa, O.E. (2007): Studies on aerobic biodegradation of 2,4-Dicholorophenoxy acetic acid (2,4-D) by petroleum degrading bacteria. - M.Sc Thesis, Obafemi Awolowa University, Ile-Ife, Nigeria.

[16] Jilani, S., Altafkhan, M. (2004): Isolation, Characterization and growth response of pesticide degrading bacteria. - J. Biol. Scie. 4(1): 15-20.

[17] Jiries, A.G., AL-Nasir, F.M., Beese, F. (2002): Pesticide and heavy metals residues in water, soil and plants in waste water disposal site near Al-Lajoun Valley, Karak, Jordan. - Water, Air, Soil Poll. 133: 97-107.

[18] Kale, S.P., Murthy, N.B.K., Raghu, K. (1989): Effect of carbofuran, carbaryl, and their metabolites on the growth of Rhizobium sp. and Azotobacter chroococcum. - Bull. Environ. Cont. Toxicol. 42(5): 769-772.

[19] Karpouzas, D., Morgan, G.J.A., Walker, A. (2000): Isolation and characterization of 23 carbofuran-degrading bacteria from soils from distant geographical areas. - Lett. Appl. Microbiol. 31: 353-358. 
[20] Kotresha, D., Vidyasagar, G.M. (2008): Isolation and characterization of phenol degrading Pseudomonas aeruginosa MTCC 4996. - World J. Microbiol. Biotech. 24: 541-547.

[21] Kuo, C.W., Genthener, B.R.S. (1996): Effect of added heavy metal ions on biotransformation and biodegradation of 2-chlorophenol and 3-chlorobenzoate in anaerobic bacterial consortia. - Appl. Environ. Microbiol. 62: 2317-2323.

[22] Leveau, J.H., Konig Fuchslin, H., Werlen, C., Van der Meer, J.R. (1999): Dyanamics of multigene expression during catabolic adaptation of Ralstonia eutropha JMP 134 (pJP4) to the herbicide 2,4-Dicholorophenoxyacetate. - Mol. Microbiol. 33: 396-406.

[23] Mallick, K., Bharati, K., Banerji, A., Shakti, N.A., Sethunathan, N. (1999): Bacterial degradation of cholorifos in pure culture and in soil. - Bull. Environ. Cont. Toxicol. 62: 48-54.

[24] Margesin, R., Schinner, F. (1997): Effects of temperature on oil degradation by a psychotrophic yeast in liquid culture and in soil. - FEMS Microbiol. Ecol. 24 : 243-249.

[25] María Celina, Z., Marisa Anahí, G. (2005): Diversity of Rhizobia isolated from an agricultural soil in Argentina based on carbon utilization and effects of herbicides on growth. - Biol. Fert. Soil. 42: 83-88.

[26] Mercadier, C., Garcia, D., Vega, D., Bastide, J., Coste, C. (2002): Metabolism of iprodione in adapted and nonadapted soils; effect of soil inoculation with iprodionedegrading Arthrobacter strain. - Soil Biol. Biochem. 28: 1791-1796.

[27] Muller, R.H., Kleinsteuber, S., Babe, W. (2001): Physical and genetic characteristics of two bacterial strains utilizing phenoxyacetate herbicides. - Microbiol. Res. 156(2): 12131.

[28] Mussarat, J., Bano, N., Rao, R.A.K. (2000): Isolation and characterization of 2,4Dichlorophenooxy acetic acid-catabolizing bacteria and their biodegradation efficiency in soil. - World J. Microbiol. Biotech. 16: 495-497.

[29] Nawab, A., Allem, A., Malik. A. (2003): Determination of organocholororie pesticides in agriculture soil with special reference to $\gamma-\mathrm{HCH}$ degradation by Pseudomonas strains. Biores. Technol. 88: 41-46.

[30] Palleroni, N.J. (1986): - In: Krieg NR, Holt JG (eds.), Bergey's Manual of Systematic Bacteriology, Volume 1, Williams and Wilkins, Baltimore.

[31] Parekh, N.R.A., Walker, S., Roberts, J., Welch, S.J. (1994): Rapid degradation of triazinone herbicide metamitron by a Rhodococcus sp. isolated from treated soil. - Appl. Bacteriol. 77: 467-475.

[32] Perrière, G., Gouy, M. (1996): WWW-Query: An on-line retrieval system for biological sequence banks. - Biochimie. 78: 364-369.

[33] Ralebits, T.K., Senior, E.H., Van Versevell, T. (2002): Microbial aspects of atrazine degradation in natural environments. - Biodegrad. 13: 11-19.

[34] Ramadan, M.A., EI-Tayeb, O.M., Alexander, M. (1990): Inoculam size as a factor limiting success of inoculation for biodegradation. - Appl. Environ. Microbiol. 56: 13921396.

[35] Rice, J.F., Menn, F.M., Hay, A.G., Sanseverino, J., Sayler, G.S. (2005): Natural selection for 2,4,5-Trichlorophenooxy acetic acid mineralizing bacteria in agent orange contaminated soil. - Biodegradation 16: 501-512.

[36] Roane, T.M., Josephson, K.L., Pepper, I.L. (2001): Dual-bioaugmentation strategy to enhance remediation of cocontaminated soil. - Appl. Environ. Microbiol. 67: 3208-3248.

[37] Sanni, G.O., Ajesebuter, S.O. (2003): Biodegradation of Escrvos light crude oil by some species of soil bacteria. - Scientific Focus 4: 87-95.

[38] Thompson, J.D., Gibson, T.J., Plewniak, F., Jeanmougin, F., Higgins, D.G. (1997): The Clustal $\mathrm{X}$ windows interface: flexible strategies for multiple sequence alignment aided by quality analysis tools. - Nucleic Acid Res. 24: 4876-4882.

[39] Viswanathan, P.N. (1985): Enviornmental toxicology in India. - Biol. Memb.11: 88-97. 